\title{
Association between direct measurement of active serum calcium and risk of type 2 diabetes mellitus: a prospective study
}

Zaccardi F ${ }^{\mathrm{a}}$, Webb DR ${ }^{\mathrm{a}}$, Carter $\mathrm{P}^{\mathrm{a}}$, Pitocco D ${ }^{\mathrm{b}}$, Khunti K ${ }^{\mathrm{a}}$, Davies MJ ${ }^{\mathrm{a}}$, Kurl S ${ }^{\mathrm{c}}$, Laukkanen JA ${ }^{\text {c,d }}$

${ }^{a}$ Diabetes Research Centre, University of Leicester, Leicester, UK

${ }^{\mathrm{b}}$ Diabetes Research Unit, Catholic University School of Medicine, Rome, Italy

${ }^{c}$ Institute of Public Health and Clinical Nutrition, University of Eastern Finland, Kuopio, Finland

d Lapland Central Hospital, Department of Internal Medicine, Rovaniemi, Finland

Word Count: Abstract 250; Text 2432

References: 38

Tables: 1; Figures: 1

Supplemental Data: 3 Tables and 2 Figures

Corresponding Author:

Dr Francesco Zaccardi

Diabetes Research Centre, Leicester General Hospital, Leicester, UK

Phone: +4401162584389 - Fax: +4401162584499

Email: frazac@fastwebnet.it

Keywords: Calcium; Ionized Calcium; Type 2 Diabetes Mellitus; Risk; Prospective Study 
Abbreviations:

T2DM Type 2 diabetes mellitus

iCa $\quad$ Ionized calcium

BMI Body mass index

HOMA-IR Homeostasis model assessment - Insulin resistance

FPG Fasting plasma glucose

CRP C-reactive protein

SD Standard deviation

HR Hazard ratio

$\log _{\mathrm{e}} \quad$ Natural logarithm

CI Confidence interval

SBP Systolic blood pressure

PTH Parathyroid hormone 


\section{ABSTRACT}

BACKGROUND AND AIMS Previous prospective studies showing a positive association between serum calcium and incidence of type 2 diabetes mellitus (T2DM) have relied on total calcium or an indirect estimate of active, ionized calcium (iCa). We aimed to assess this relationship using a direct measurement of iCa.

METHODS AND RESULTS iCa and cardiometabolic risk factors were measured in a population-based sample of 2350 men without a known history of T2DM at baseline. Associations between iCa levels and incident cases of T2DM (self-reported, ascertained with a glucose tolerance test, or determined by record linkage to national registers) were estimated using Cox regression analyses adjusted for potential confounders. At baseline, mean (standard deviation) age was 53 (5) years and mean iCa $1.18(0.05) \mathrm{mmol} / \mathrm{L}$. During a median follow-up of 23.1 years, 140 new cases of T2DM were recorded. In a multivariable analysis adjusted for age, body mass index, systolic blood pressure, serum HDL-cholesterol, and family history of T2DM, there was no association comparing second (hazard ratio $0.84 ; 95 \%$ confidence interval $0.59-1.18)$, third $(0.77 ; 0.52-1.14)$, or fourth $(0.98 ; 0.69-1.39)$ vs first quartile of $\mathrm{iCa}$ ( $\mathrm{p}$ for trend 0.538 ); further adjustment for C-reactive protein, physical activity level, and triglycerides did not change the estimates ( $\mathrm{p}$ for trend 0.389).

CONCLUSION In this study, we did not find evidence of an association between direct measurement of active calcium and risk of T2DM. Further studies are needed to confirm our findings and define the relationship between factors influencing indirect calcium estimation and incident T2DM. 


\section{INTRODUCTION}

Type 2 diabetes mellitus (T2DM) is a metabolic disorder whose major clinical feature is hyperglycemia (1). Numerous recent studies have highlighted the complexity of its pathophysiology, including abnormal gut/ $\beta$-cell cross-talk, insufficient insulin secretion, and a reduced insulin action in peripheral tissues (2).

Calcium plays an active role in both insulin secretion and its peripheral effects. Glucose-dependent insulin exocytosis is a calcium-regulated process, being dependent upon $\beta$-cell intracellular calcium concentration (3). Calcium is an established regulator of GLUT4 expression, a passive transporter essential for peripheral glucose uptake (4). As a consequence, abnormalities in calcium homeostasis could potentially affect glucose metabolism and contribute to the development of T2DM (5).

A possible association between calcium and T2DM risk has been explored in nutritional epidemiology studies: the available evidence, though, is limited because most studies are cross-sectional and did not adjust for important confounders (6). Similarly, crosssectional and case-control studies investigating the relationship between calcium homeostasis and glucose metabolism have reported conflicting results (7-15); however, only a few studies have prospectively evaluated the association between serum calcium and risk of incident T2DM, suggesting that higher levels of serum calcium predict an increased risk of T2DM (16-18). These studies have relied either on total serum calcium or the indirect, albumincorrected estimate of serum calcium: these measurements, however, only approximate the levels biological-active serum calcium (iCa) (19). Interestingly, a previous case-control study did not find an association between directly measured $\mathrm{iCa}$ and prevalent diabetes (11); similarly, in another small study, no association was found between direct iCa measurement and indices of diabetes control (15). 
To our knowledge, the relationship between directly measured $\mathrm{iCa}$ and the risk of incident T2DM has not been investigated in a prospective study setting. Thus, our aim was to evaluate the risk of $\mathrm{T} 2 \mathrm{DM}$ in a population-based study using direct measurement of iCa levels. 


\section{METHODS}

This study was performed following the STROBE guidelines for observational studies (20).

\section{Study population}

The Kuopio Ischaemic Heart Disease risk factor study was designed to investigate risk predictors for atherosclerotic cardiovascular outcomes in a population-based sample of men from Eastern Finland. The subjects were a randomly selected sample of men 42 to 60 years of age resident in the town of Kuopio and its surrounding rural communities obtained from the national population register (21); baseline examinations were conducted between March 1984 and December 1989.

Of the 3433 invited, $2682(78.1 \%)$ participated. In this study, participants were excluded if they were diagnosed with diabetes at baseline $(n=162)$, defined as either having regular treatment with an oral hypoglycemic agent, insulin therapy, or having treatment only with diet while also having a fasting plasma glucose level of at least $7.0 \mathrm{mmol} / \mathrm{L}$. We further excluded those subjects with missing baseline information on calcium $(n=170)$. Therefore, data on 2350 participants were available for the analyses. Incident case of T2DM was defined as a self-reported physician-set diagnosis and/or fasting plasma glucose $\geq 7.0 \mathrm{mmol} / \mathrm{L}$ or 2 -h oral glucose tolerance test plasma glucose $\geq 11.1 \mathrm{mmol} / \mathrm{L}$ at re-examination rounds 4,11 , and 20 years after baseline, and by record linkage to the national hospital discharge registry and to the Social Insurance Institution of Finland register for reimbursement of medicine expenses.

\section{Assessment of risk factors}


Prior to attendance at the baseline appointment, participants were instructed to abstain from drinking alcohol for a minimum of 3 days and from smoking for at least 12 hours. Fasting blood samples were taken following a 30-minute rest period in the supine position and collected using vacuum tubes (Terumo Venoject; Terumo, Tokyo, Japan).

The resting blood pressure was measured with a random-zero sphygmomanometer (Hawksley, Lancing England) by two trained nurses. A total of six measurements (3 supine, 1 standing, and 2 sitting) were taken following a 5 minute supine rest and blood pressure was taken as the mean of all six measurements. Baseline medical history, smoking habits, years of education, family history of T2DM (defined as positive if a first-degree relative of the subject had T2DM history), and drug therapy were assessed by self-administered questionnaires. The diagnosis of chronic diseases was checked during a medical examination by the internist. Detailed descriptions on physical activity estimation have been published previously (22). Body mass index (BMI) was computed as the ratio of weight in kilograms to the square of height in meters.

The measurement of serum active calcium concentrations (23) was made using ion selective electrodes (Microlyte 6, Kone, Finland; CV, 1.6\%; reference interval, 1.16-1.32 mmol/l). Serum insulin level was determined using a radioimmunoassay kit (Novo Biolabs; Novo Nordisk, Bagsvaerd, Denmark). The serum samples were stored frozen at $-80^{\circ} \mathrm{C}$ for 0.2-2.5 years. The values obtained were immunoreactive insulin as the assay has cross reactivity with proinsulin. A glucose dehydrogenase method (Merck, Darmstadt, Germany) was used to assess blood glucose after precipitation of proteins by trichloroacetic acid. Insulin resistance was estimated as follows: HOMA-IR = fasting plasma insulin $(\mu \mathrm{U} / \mathrm{mL}) \mathrm{x}$ fasting plasma glucose $(\mathrm{FPG})(\mathrm{mmol} / \mathrm{L}) / 22.5$. The cholesterol contents of lipoprotein fractions and serum triglycerides were measured enzymatically (Boehringer Mannheim, Mannheim Germany). High-density lipoprotein (HDL) was separated from fresh samples by 
ultracentrifugation and precipitation, low-density lipoprotein (LDL) was estimated as total cholesterol-HDL-triglycerides/5. Serum C-reactive protein (CRP) was measured with an immunometric assay (Immulite High Sensitivity C-Reactive Protein Assay; DPC, Los Angeles, CA).

\section{Statistical analysis}

For all the analyses, natural logarithm $\left(\log _{\mathrm{e}}\right)$ transformed values of non-normal distributed variables (triglycerides, CRP, HOMA-IR, years of education, alcohol consumption, and physical activity) were used. Descriptive data are presented as means and standard deviations (SD) or medians and interquartile ranges for continuous variables, and percentages for categorical values. Correlation coefficients were calculated to assess the correlation between baseline calcium levels and other continuous variables, whereas mean differences between groups were calculated for categorical factors.

Analyses of the associations between $\mathrm{iCa}$ and incident T2DM involved Coxregression modelling. The proportional hazards assumption was verified for all variables by inspection of the plots of the Schoenfeld residual for covariates. Shapes of association were assessed by plotting hazard ratios (HRs) estimated within quartiles of calcium relative to the bottom quartile against the mean calcium level in each quartile; 95\% confidence intervals (CIs) were estimated from variances attributed to the groups to reflect the amount of information within each group (including the reference category (24)). To assess the independence of association between calcium and incident cases of T2DM, we calculated quartiles HRs with progressive adjustment for potential confounders selected on the basis of their previously established role as predictive factors. In model 1, we included age, BMI, systolic blood pressure (SBP), serum HDL-cholesterol, and family history of T2DM; in model 2, we added CRP, physical activity, and serum triglyceride concentrations. Model 3a 
included variables in model 2 plus HOMA-IR, while model $3 \mathrm{~b}$ variables in model 2 plus FPG.

All analyses were performed with Stata 13 (Stata Corp, College Station, TX, USA), and two-sided $P$-value $<0.05$ was considered statistically significant. 


\section{RESULTS}

\section{Baseline characteristics and numbers of outcome events during follow-up}

At baseline, mean (SD) age, BMI and iCa were 53 (5) years, 26.7 (3.4) $\mathrm{Kg} / \mathrm{m}^{2}$ and $1.18(0.05) \mathrm{mmol} / \mathrm{L}$, respectively. Baseline characteristics of the study population and correlation coefficients between $\mathrm{iCa}$ and other variables are reported in Table 1 and Supplemental Table S1, respectively. Levels of cardiometabolic risk factors (i.e., BMI, triglycerides, FPG, HOMA-IR) were higher in subjects who had developed T2DM during follow-up as compared to subjects who had not (Table 1).

During a median follow-up of 23.1 (interquartile range: 16.2-25.1) years, a total of $140(5.9 \%)$ new cases of T2DM were recorded, with an unadjusted incidence rate of 2.89 (95\% CI: 2.45-3.41) per 1000 person-years.

\section{Calcium as risk factor for incident type 2 diabetes mellitus}

The relationship between baseline calcium levels and incident T2DM, progressively adjusted for potential confounders, is shown in Figure 1 (HRs are reported in Supplemental Table S2). In multivariable analysis adjusted for age, BMI, SBP, serum HDL-cholesterol, and family history of T2DM (model 1), we did not find an association between iCa and risk of T2DM: compared to the first quartile of $\mathrm{iCa}$, the HRs for the second, third, and fourth quartiles were 0.84 (95\% confidence interval: $0.59-1.18), 0.77(0.52-1.14)$, and 0.98 (0.691.39), respectively ( $\mathrm{p}$ for trend 0.538; Figure 1 and Supplemental Table S2). The respective HRs, upon further adjustment for CRP, physical activity level, and triglycerides, were 0.89 (0.63-1.26), $0.79(0.52-1.17)$, and $0.87(0.61-1.26)$; $\mathrm{p}$ for trend 0.389 . Similar nonsignificant associations were found after further inclusion of HOMA-IR (model 3a; $\mathrm{p}$ for trend 0.557 ) or FPG (model 3b; $\mathrm{p}$ for trend 0.330 ). 


\section{DISCUSSION}

Our results indicate that, in this cohort of middle-age Finnish men, direct measurement of active, ionized serum calcium is not associated with incident T2DM.

T2DM is a major cause of morbidity and mortality in the developed and developing world (25). Although much progress has been made in describing its physiopathology, there is a growing interest in the identification of new biomarkers to help clarify its aetiology or define subjects at higher risk of developing T2DM. The relationship between calcium and glucose homeostasis has long been recognized, with case-control studies assessing calcium fractions dating back to 1960 s (26). In parallel with observational work, experimental studies have described the role of calcium at the cellular and molecular level, clarifying fundamental second messenger functions in insulin secretion (3) and action $(4,27)$.

Previous non-prospective observational studies have reported conflicting results about calcium levels (plasma, total serum, or albumin-corrected serum concentrations) and glucose homeostasis. In T2DM subjects, calcium levels have been shown to be higher $(10,13)$ and associated with fasting glucose or insulin resistance $(8,9,12)$; conversely, other studies have reported no relationship with markers of glucose control (15), insulin resistance (7), or insulin secretion $(7,9)$.

To our knowledge, only three studies have prospectively assessed the relationship between incident diabetes and calcium concentrations. The characteristics and a graphical summary of the results are reported in Supplemental Table S3 and Supplemental Figure S1. A large Norwegian study has assessed the association between non-fasting total serum calcium and risk of T2DM, cancer, and cardiovascular disease, showing a positive relationship with T2DM (16). However, this study has also shown no relationship between two single nucleotide polymorphisms associated with calcium concentration (rs1801725 and 
rs 17251221) and risk of diabetes. More recently, two other smaller studies have investigated the link between fasting albumin-corrected serum calcium and incident T2DM, reporting positive associations $(17,18)$. Of note, in both studies the Authors acknowledged as a major limitation the unavailability of direct measurement of iCa.

Direct measurement of active, ionized calcium is regarded as the gold standard of calcium measurement $(19,23,28)$. In normal conditions, about $50 \%$ of total serum calcium is present in $\mathrm{iCa}$ form, $35-40 \%$ is bound to negatively charged amino acid residues of proteins, and the remaining $10-15 \%$ is linked to small organic molecules (i.e., bicarbonate, citrate, sulfate, phosphate, lactate) to form complexes (23); therefore, conditions modifying one or more of these compounds could potentially result in changes of calcium fractions. In particular, alterations in albumin concentration, blood $\mathrm{pH}$, use of drugs, or fatty acids bound to albumin change the ratio between total and $\mathrm{iCa}(19)$. As the primary, most abundant negatively charged serum protein is albumin, a common equation is used to estimate the "albumin-adjusted" total calcium. This equation is derived from healthy volunteers, is valid only for specific combinations of total calcium and albumin assays within given reference intervals, and assumes a constant binding capacity of albumin $(1 \mathrm{~g} / \mathrm{dL}$ albumin binds approximately $0.8 \mathrm{mg} / \mathrm{dL}$ calcium) $(19,23)$. In subjects with T2DM there are many factors potentially modifying calcium fractions. In particular, high levels of circulating free fatty acids are known to alter calcium-albumin binding (29) and are also associated with incident risk of T2DM (30). In this situation total or albumin-corrected estimation of serum calcium can be biased (11) (Supplemental Figure S2). Similarly, higher levels of plasma lactate are associated with incident T2DM (31) and could modify calcium fractions (28). Lastly, it is worth noting that adjustment for albumin concentration has been proposed for another biomarker associated with incident T2DM (fructosamine) $(32,33)$, although it is still unclear the appropriateness of such adjustment given (34). 
Interestingly, our results are in line with a previous study showing no difference in direct $\mathrm{iCa}$ measurement comparing subjects with and without diabetes (11); notably, the Authors speculated that 'correction' of total calcium for serum albumin would not be appropriate because of an increased serum free fatty acids concentrations. Similarly, in another study, direct measurement of iCa was not associated with indices of diabetes control (15). Notwithstanding the different exposure assessment, our results could be related to heterogeneous characteristics between populations (i.e., age, sex, race, or genetic background); or due to the ascertainment of outcomes; or associated to statistical planning and analysis; or a combination of all these. Notably, inherited characteristics, along with environmental factors, could explain the low values of iCa in our population. In fact, at high latitudes cutaneous synthesis of vitamin D is reduced, thus potentially resulting in low calcium levels (35).

We should acknowledge some limitations and strengths of this study. First, a generalisation of our findings is defined by the study population, consisting of middle-age Finnish men only: these findings need to be confirmed in other ethnic groups and in females. Second, we could not correct for a possible regression dilution bias (36), as we had only baseline assessment of iCa values. Nonetheless, for covariates with available repeated measurements, we have observed a rather stable "phenotype" (33). Third, our study did not collect information about parathyroid hormone $(\mathrm{PTH})$ and vitamin D for all participants; therefore, it was not possible to adjust for these variables or to exclude subjects at high risk of primary or secondary hyperparathyroidism, also implicated with glucose metabolism $(5,37)$. However, adjustment for PTH (or vitamin D) requires that such a variable is associated with T2DM independent of $\mathrm{iCa}$ (38), an assumption that needs to be verified. Fourth, as $\mathrm{pH}$ influences direct $\mathrm{iCa}$ measurement, it could be considered a confounder; this hypothesis 
could not be tested in our analysis, lacking baseline $\mathrm{pH}$ data. Yet, up to our knowledge, no available evidence suggests a relationship between $\mathrm{pH}$ and T2DM. Whether $\mathrm{pH}$ is a confounding factor, however, should be verified in future studies. On the other hand, strengths of this study include the rigorous measurement of baseline risk factors and assessment of T2DM, the large and homogeneous community-based sample, and the longterm follow-up.

In conclusion, in our cohort of middle-age Finnish men, direct measurement of iCa levels were not associated with incident T2DM risk. Further studies are needed to confirm our findings and elucidate the relationship between calcium and glucose metabolism. 


\section{ACKNOWLEDGMENT}

We thank the staff of the Kuopio Research Institute of Exercise Medicine and the Research Institute of Public Health, University of Eastern Finland, for data collection.

We acknowledge the support of the following institutes in this work: the National Institute for Health Research, Collaboration for Leadership in Applied Health Research and Care - East Midlands (NIHR CLARHC East Midlands); and the National Institute for Health Research (NIHR) Diet, Lifestyle \& Physical Activity Biomedical Research Unit based at University Hospitals of Leicester and Loughborough University. The views expressed are those of the authors and not necessarily those of the NHS, the NIHR or the Department of Health.

We thank two anonymous reviewers for their helpful comments and suggestions.

\section{CONTRIBUTION}

FZ: conception of the idea, analysis of data, drafting of the manuscript.

DRW, PC, DP, KK, MJD: interpretation of data, critical revision of the manuscript for important intellectual content, drafting of the manuscript.

SK: acquisition of data, administrative and technical support.

JAL: conception of the idea, interpretation of data, critical revision of the manuscript for important intellectual content, drafting of the manuscript.

FZ had full access to all the data in the study and takes responsibility for the integrity of the data and the accuracy of the data analysis.

\section{ETHICS}

The study was approved by the Research Ethics Committee of the University of Eastern Finland. Each participant gave written informed consent. 


\section{CONFLICT OF INTEREST}

KK has acted as a consultant and speaker for Novartis, Novo Nordisk, Sanofi-Aventis, Lilly and Merck Sharp \& Dohme. He has received grants in support of investigator and investigator initiated trials from Novartis, Novo Nordisk, Sanofi-Aventis, Lilly, Pfizer, Boehringer Ingelheim and Merck Sharp \& Dohme. KK has received funds for research, honoraria for speaking at meetings and has served on advisory boards for Lilly, SanofiAventis, Merck Sharp \& Dohme and Novo Nordisk.

MJD has acted as consultant, advisory board member and speaker for Novo Nordisk, SanofiAventis, Lilly, Merck Sharp \& Dohme, Boehringer Ingelheim, AstraZeneca and Janssen and as a speaker for Mitsubishi Tanabe Pharma Corporation. She has received grants in support of investigator and investigator initiated trials from Novo Nordisk, Sanofi-Aventis and Lilly. All other Authors have no conflict of interests to disclose.

\section{FUNDINGS}

The research was supported by the National Institute for Health Research (NIHR) Diet, Lifestyle \& Physical Activity Biomedical Research Unit based at University Hospitals of Leicester and Loughborough University. The views expressed are those of the authors and not necessarily those of the NHS, the NIHR or the Department of Health. 


\section{REFERENCES}

1. Inzucchi SE. Clinical practice. Diagnosis of diabetes. N Engl J Med 2012; 367:542-50.

2. Defronzo RA. Banting Lecture. From the triumvirate to the ominous octet: a new paradigm for the treatment of type 2 diabetes mellitus. Diabetes 2009; 58:773-95.

3. Wollheim CB, Sharp GW. Regulation of insulin release by calcium. Physiol Rev 1981; 61:914-73.

4. Ojuka EO, Jones TE, Nolte LA, Chen M, Wamhoff BR, Sturek M, Holloszy JO. Regulation of GLUT4 biogenesis in muscle: evidence for involvement of AMPK and Ca(2+). Am J Physiol Endocrinol Metab 2002; 282:E1008-13.

5. Procopio M, Magro G, Cesario F, Piovesan A, Pia A, Molineri N, Borretta G. The oral glucose tolerance test reveals a high frequency of both impaired glucose tolerance and undiagnosed Type 2 diabetes mellitus in primary hyperparathyroidism. Diabet Med 2002; 19:958-61.

6. Pittas AG, Lau J, Hu FB, Dawson-Hughes B. The role of vitamin D and calcium in type 2 diabetes. A systematic review and meta-analysis. J Clin Endocrinol Metab 2007; 92:2017-29.

7. Wareham NJ, Byrne CD, Carr C, Day NE, Boucher BJ, Hales CN. Glucose intolerance is associated with altered calcium homeostasis: a possible link between increased serum calcium concentration and cardiovascular disease mortality. Metabolism 1997; 46:11717.

8. Sun G, Vasdev S, Martin GR, Gadag V, Zhang H. Altered calcium homeostasis is correlated with abnormalities of fasting serum glucose, insulin resistance, and $\beta$-cell function in the Newfoundland population. Diabetes 2005; 54:3336-9. 
9. Hagström E, Hellman P, Lundgren E, Lind L, Arnlöv J. Serum calcium is independently associated with insulin sensitivity measured with euglycaemic-hyperinsulinaemic clamp in a community-based cohort. Diabetologia 2007; 50:317-24.

10. Levy J, Stern Z, Gutman A, Naparstek Y, Gavin JR 3rd, Avioli LV. Plasma calcium and phosphate levels in an adult noninsulin-dependent diabetic population. Calcif Tissue Int $1986 ; 39: 316-8$.

11. Sorva A, Tilvis RS. Low serum ionized to total calcium ratio: association with geriatric diabetes mellitus and with other cardiovascular risk factors? Gerontology 1990; 36:2126.

12. Yamaguchi T, Kanazawa I, Takaoka S, Sugimoto T. Serum calcium is positively correlated with fasting plasma glucose and insulin resistance, independent of parathyroid hormone, in male patients with type 2 diabetes mellitus. Metabolism 2011; 60:1334-9.

13. Kim MK, Kim G, Jang EH, Kwon HS, Baek KH, Oh KW, et al. Altered calcium homeostasis is correlated with the presence of metabolic syndrome and diabetes in middle-aged and elderly Korean subjects: the Chungju Metabolic Disease Cohort study (CMC study). Atherosclerosis 2010; 212:674-81.

14. Heath H 3rd, Lambert PW, Service FJ, Arnaud SB. Calcium homeostasis in diabetes mellitus. J Clin Endocrinol Metab 1979; 49:462-6.

15. McNair P, Fogh-Andersen N, Madsbad S, Christensen MS. Decreased serum concentration of ionized calcium in insulin-dependent human diabetes mellitus. Eur $\mathbf{J}$ Clin Invest 1983; 13:267-70.

16. Jorde R, Schirmer H, Njølstad I, Løchen ML, Bøgeberg Mathiesen E, Kamycheva E, et al. Serum calcium and the calcium-sensing receptor polymorphism rs17251221 in relation to coronary heart disease, type 2 diabetes, cancer and mortality: the Troms $\varnothing$ Study. Eur J Epidemiol 2013; 28:569-78. 
17. Lorenzo C, Hanley AJ, Rewers MJ, Haffner SM. Calcium and phosphate concentrations and future development of type 2 diabetes: the Insulin Resistance Atherosclerosis Study. Diabetologia 2014; 57:1366-74.

18. Becerra-Tomás N, Estruch R, Bulló M, Casas R, Díaz-López A, Basora J, et al. Increased serum calcium levels and risk of type 2 diabetes in individuals at high cardiovascular risk. Diabetes Care 2014; 37:3084-91.

19. Calvi LM, Bushinsky DA. When is it appropriate to order an ionized calcium? J Am Soc Nephrol 2008; 19:1257-60.

20. Available from http://www.strobe-statement.org/. Accessed 29 November 2014

21. Salonen JT. Is there a continuing need for longitudinal epidemiologic research? The Kuopio Ischaemic Heart Disease Risk Factor Study. Ann Clin Res 1988; 20:46-50.

22. Lakka TA, Venäläinen JM, Rauramaa R, Salonen R, Tuomilehto J, Salonen JT. Relation of leisure-time physical activity and cardiorespiratory fitness to the risk of acute myocardial infarction. N Engl J Med 1994; 330:1549-54.

23. Baird GS. Ionized calcium. Clin Chim Acta 2011; 412:696-701.

24. Easton DF, Peto J, Babiker AG. Floating absolute risk: an alternative to relative risk in survival and case-control analysis avoiding an arbitrary reference group. Stat Med 1991; 10:1025-35.

25. Available from http://www.idf.org/sites/default/files/EN_6E_Atlas_Full_0.pdf. Accessed 29 November 2014

26. Jasiński K, Adamski A, Smarsz C. Plasma calcium fractions in diabetes mellitus. Pol Med J 1968; 7:1033-40.

27. Contreras-Ferrat A, Lavandero S, Jaimovich E, Klip A. Calcium signaling in insulin action on striated muscle. Cell Calcium 2014 Sep 6 [Epub ahead of print].

28. Bushinsky DA, Monk RD. Electrolyte quintet: Calcium. Lancet 1998; 352:306-11. 
29. Zaloga GP, Willey S, Tomasic P, Chernow B. Free fatty acids alter calcium binding: a cause for misinterpretation of serum calcium values and hypocalcemia in critical illness. J Clin Endocrinol Metab 1987; 64:1010-4.

30. Virtanen JK, Mursu J, Voutilainen S, Uusitupa M, Tuomainen TP. Serum omega-3 polyunsaturated fatty acids and risk of incident type 2 diabetes in men: the Kuopio Ischemic Heart Disease Risk Factor study. Diabetes Care 2014; 37:189-96.

31. Juraschek SP, Selvin E, Miller ER, Brancati FL, Young JH. Plasma lactate and diabetes risk in 8045 participants of the atherosclerosis risk in communities study. Ann Epidemiol $2013 ; 23: 791-6$.

32. Selvin E, Rawlings AM, Grams M, Klein R, Sharrett AR, Steffes M, Coresh J. Fructosamine and glycated albumin for risk stratification and prediction of incident diabetes and microvascular complications: a prospective cohort analysis of the Atherosclerosis Risk in Communities (ARIC) study. Lancet Diabetes Endocrinol 2014; 2:279-88.

33. Zaccardi F, Kurl S, Pitocco D, Ronkainen K, Laukkanen JA. Serum fructosamine and risk of type 2 diabetes mellitus among middle-age Finnish men: a 23-year populationbased prospective study. Acta Diabetol 2014 Jul 16 [Epub ahead of print].

34. Goldstein DE, Little RR, Lorenz RA, Malone JI, Nathan DM, Peterson CM; American Diabetes Association. Tests of glycemia in diabetes. Diabetes Care 2003; 26 Suppl $1:$ S106-8.

35. Webb AR, Holick MF. The role of sunlight in the cutaneous production of vitamin D3. Annu Rev Nutr 1988; 8:75-99.

36. Hughes MD. Regression dilution in the proportional hazards model. Biometrics 1993; 49:1056-66. 
37. Zhao G, Ford ES, Li C. Associations of serum concentrations of 25-hydroxyvitamin D and parathyroid hormone with surrogate markers of insulin resistance among U.S. adults without physician-diagnosed diabetes: NHANES, 2003-2006. Diabetes Care 2010; $33: 344-7$.

38. Rothman KJ, Greenland S, Lash TL. Modern epidemiology, 3rd ed. Philadelphia, PA: Lippincott-Raven, 2008. 


\section{FIGURE LEGENDS}

FIGURE 1: Hazard ratios and 95\% confidence intervals (bars) of type 2 diabetes mellitus by quartiles of baseline active calcium levels.

Legend: Variables included in the models. Model 1: Age, body mass index, systolic blood pressure, serum HDL-cholesterol and family history of type 2 diabetes mellitus; Model 2: Model 1 plus Creactive protein, physical activity and serum triglyceride; Model 3a: Model 2 plus HOMA-IR; Model 3b: Model 2 plus fasting plasma glucose. 


\section{Supplemental Data}

Association between direct measurement of active serum calcium and risk of type 2 diabetes mellitus: a prospective study

Zaccardi F ${ }^{\mathrm{a}}$, Webb DR ${ }^{\mathrm{a}}$, Carter $\mathrm{P}^{\mathrm{a}}$, Pitocco D ${ }^{\mathrm{b}}$, Khunti K ${ }^{\mathrm{a}}$, Davies MJ ${ }^{\mathrm{a}}$, Kurl S ${ }^{\mathrm{c}}$, Laukkanen JA ${ }^{\mathrm{c}, \mathrm{d}}$

${ }^{1}$ Diabetes Research Centre, University of Leicester, Leicester, UK

${ }^{2}$ Diabetes Research Unit, Catholic University School of Medicine, Rome, Italy

${ }^{3}$ Institute of Public Health and Clinical Nutrition, University of Eastern Finland, Kuopio, Finland

${ }^{4}$ Lapland Central Hospital, Department of Internal Medicine, Rovaniemi, Finland

Supplementary Tables: 3

Supplementary Figures: 2 
Supplemental Table S1: Unadjusted correlation coefficients (r) between active serum calcium and other baseline covariates.

\author{
Variable \\ Age (years) \\ Body mass index $\left(\mathrm{kg} / \mathrm{m}^{2}\right)$ \\ Systolic blood pressure $(\mathrm{mmHg})$ \\ LDL-cholesterol ( $\mathrm{mmol} / \mathrm{L})$ \\ HDL-cholesterol ( $\mathrm{mmol} / \mathrm{L})$ \\ $\log _{\mathrm{e}}$ Triglycerides $(\mathrm{mmol} / \mathrm{L})$ \\ Fasting plasma glucose $(\mathrm{mmol} / \mathrm{L})$ \\ $\log _{\mathrm{e}}$ C-reactive protein $(\mathrm{mg} / \mathrm{L})$ \\ $\log _{\mathrm{e}}$ HOMA-IR \\ Smoking (yes) \\ Family history of diabetes (yes) \\ $\log _{\mathrm{e}}$ Education (years) \\ $\log _{\mathrm{e}}$ Alcohol (g/week) \\ $\log _{\mathrm{e}}$ Physical activity (kcal/day)
}

\begin{tabular}{rrrr} 
r or difference $(\mathbf{9 5 \%} \mathbf{C I})$ & & p-value \\
\cline { 1 - 1 }$-0.065(0.024,0.105)$ & & 0.002 \\
$-0.061(-0.101,-0.020)$ & & 0.003 \\
$-0.021(-0.062,0.019)$ & & 0.302 \\
$0.114(0.074,0.154)$ & & $<0.001$ \\
$-0.017(-0.057,0.024)$ & & 0.412 \\
$-0.092(-0.131,-0.051)$ & & $<0.001$ \\
$-0.007(-0.048,0.033)$ & & 0.729 \\
$-0.038(-0.078,0.003)$ & & 0.067 \\
$0.039(-0.002,0.080)$ & & 0.061 \\
$0.55 \%(0.18,0.93)$ & & 0.004 \\
$0.18 \%(-0.21,0.58)$ & & 0.359 \\
$-0.116(-0.155,-0.076)$ & & $<0.001$ \\
$-0.008(-0.052,0.035)$ & & 0.707 \\
$0.001(-0.040,0.041)$ & & 0.976
\end{tabular}


Supplemental Table S2: Hazard ratios (HRs) of type 2 diabetes mellitus, by quartiles of baseline active calcium serum levels.

Active serum calcium quartiles (mmol/L) [Range; mean]

\begin{tabular}{|c|c|c|c|c|}
\hline Model & $\begin{array}{c}\text { Quartile 1 } \\
{[0.88-1.15 ; 1.12]}\end{array}$ & $\begin{array}{c}\text { Quartile 2 } \\
\text { [1.16-1.18; 1.17] }\end{array}$ & $\begin{array}{c}\text { Quartile 3 } \\
{[1.19-1.21 ; 1.20]}\end{array}$ & $\begin{array}{c}\text { Quartile 4 } \\
{[1.22-1.50 ; 1.24]}\end{array}$ \\
\hline No. of Cases/Participants & $47 / 740$ & $33 / 578$ & $25 / 525$ & $35 / 507$ \\
\hline $\begin{array}{l}\text { Model 2: HRs (95\% CIs) } \\
\text { p-value }\end{array}$ & $\begin{array}{c}1.00(0.74,1.35) \\
-\end{array}$ & $\begin{array}{c}0.89(0.63,1.26) \\
0.532\end{array}$ & $\begin{array}{c}0.79(0.52,1.17) \\
0.243\end{array}$ & $\begin{array}{c}0.87(0.61,1.26) \\
0.486\end{array}$ \\
\hline $\begin{array}{l}\text { Model 3a: HRs (95\% CIs) } \\
\text { p-value }\end{array}$ & $\begin{array}{c}1.00(0.73,1.36) \\
-\end{array}$ & $\begin{array}{c}0.93(0.65,1.33) \\
0.718\end{array}$ & $\begin{array}{c}0.80(0.53,1.21) \\
0.291\end{array}$ & $\begin{array}{c}0.82(0.56,1.20) \\
0.317\end{array}$ \\
\hline $\begin{array}{l}\text { Model 3b: HRs (95\% CIs) } \\
\text { p-value }\end{array}$ & $\begin{array}{c}1.00(0.74,1.35) \\
-\end{array}$ & $\begin{array}{c}0.87(0.61,1.23) \\
0.447\end{array}$ & $\begin{array}{c}0.79(0.53,1.18) \\
0.251\end{array}$ & $\begin{array}{c}0.86(0.59,1.23) \\
0.409\end{array}$ \\
\hline
\end{tabular}

Covariates included in the analyses:

Model 1: Age, body mass index, systolic blood pressure, serum HDL-cholesterol and family history type 2 diabetes mellitus

Model 2: Model 1 plus C-reactive protein, physical activity and serum triglyceride

Model 3a: Model 2 plus HOMA-IR

Model 3b: Model 2 plus fasting plasma glucose 
Supplemental Table S3: Summary of the characteristics of the previous studies assessing serum calcium and risk of type 2 diabetes mellitus

\begin{tabular}{|c|c|c|c|c|c|c|c|c|c|c|c|}
\hline \multirow{2}{*}{$\begin{array}{l}\text { Author (Ref) } \\
\text { Study }\end{array}$} & \multicolumn{2}{|c|}{ Number of } & \multirow{2}{*}{$\begin{array}{c}\text { Male } \\
(\%)\end{array}$} & \multirow{2}{*}{$\begin{array}{c}\text { Mean } \\
\text { Age (yrs) } \\
\end{array}$} & \multirow{2}{*}{$\begin{array}{c}\text { Follow-up } \\
(\mathrm{yrs})\end{array}$} & \multirow{2}{*}{$\begin{array}{l}\text { Population } \\
\text { Sample } \\
\end{array}$} & \multirow{2}{*}{$\begin{array}{l}\text { Exposure } \\
\text { definition }\end{array}$} & \multirow{2}{*}{$\begin{array}{l}\text { Exposure } \\
\text { assessment }\end{array}$} & \multirow{2}{*}{$\begin{array}{l}\text { Endpoint } \\
\text { definition }\end{array}$} & \multirow{2}{*}{$\begin{array}{l}\text { Endpoint } \\
\text { ascertainment }\end{array}$} & \multirow{2}{*}{ Confounders } \\
\hline & Participants & Cases & & & & & & & & & \\
\hline $\begin{array}{l}\text { Becerra-Tomas } \\
(18) \\
\text { Prospective } \\
\text { Cohort } \\
\text { Spain, } \\
2014\end{array}$ & 707 & 77 & 40 & 67 & $\begin{array}{c}4.78 \\
\text { (median) } \\
\\
\text { Interquartile } \\
\text { Range: } \\
2.60-5.74\end{array}$ & $\begin{array}{l}\text { Post-hoc analysis of } \\
\text { PREDIMED randomized } \\
\text { clinical trial with available data } \\
\text { on calcaemia. }\end{array}$ & $\begin{array}{l}\text { Fasting albumin- } \\
\text { corrected } \\
\text { calcemia* } \\
\text { Reference range } \\
2.05-2.58 \mathrm{mmol} / \mathrm{L}\end{array}$ & $\begin{array}{l}\text { Automated techniques } \\
\text { using COBAS integra } \\
\text { reagents }\end{array}$ & $\begin{array}{l}\text { American Diabetes } \\
\text { Association criteria }\end{array}$ & $\begin{array}{l}\text { Blood test of subjects } \\
\text { with medical records } \\
\text { positive for T2DM }\end{array}$ & $\begin{array}{l}\text { Age, sex, intervention } \\
\text { group, BMI, smoking } \\
\text { status, educational } \\
\text { level, prevalence of } \\
\text { hypertension and } \\
\text { hypercholesterolemia, } \\
\text { antihypertensive } \\
\text { medication and statins, } \\
\text { alcohol intake, leisure } \\
\text { time physical activity, } \\
\text { fasting plasma glucose }\end{array}$ \\
\hline $\begin{array}{l}\text { Jorde (16) } \\
\text { Prospective } \\
\text { Cohort } \\
\text { Norway, } 2013\end{array}$ & 25657 & 705 & 48 & 47 & $\begin{array}{c}8 \\
\text { (median) }\end{array}$ & $\begin{array}{l}\text { Subjects } 25-97 \text { year-old } \\
\text { participating in the } 4 \text { th } \\
\text { (1994-5) survey of the Troms } \varnothing \\
\text { population-based prospective } \\
\text { study and followed up to the } 6^{\text {th }} \\
\text { (2007-8) survey }\end{array}$ & $\begin{array}{l}\text { Nonfasting total } \\
\text { calcemia } \\
\text { Reference range } \\
2.20-2.60 \\
\mathrm{mmol} / \mathrm{L}\end{array}$ & Not reported & $\begin{array}{l}\text { Self-reported, } \\
\text { registries, or } \\
\text { HbA1c }>6.5 \%\end{array}$ & $\begin{array}{l}\text { Verified cases from self- } \\
\text { reported and linkage to } \\
\text { University Hospital of } \\
\text { North Norway discharge } \\
\text { diagnosis or to the Cause } \\
\text { of Death Registry }\end{array}$ & $\begin{array}{l}\text { Age, sex, BMI, } \\
\text { smoking status, systolic } \\
\text { blood pressure, serum } \\
\text { cholesterol }\end{array}$ \\
\hline $\begin{array}{l}\text { Lorenzo (17) } \\
\text { Prospective } \\
\text { Cohort } \\
\text { US, } \\
2014\end{array}$ & 863 & 140 & 40 & 55 & $\begin{array}{c}\begin{array}{c}5.2 \\
\text { (mean) }\end{array} \\
\text { Range: } \\
4.5-6.6\end{array}$ & $\begin{array}{l}\text { Subjects } 40-69 \text { year-old } \\
\text { participating in the Insulin } \\
\text { Resistance Atherosclerosis } \\
\text { Study (IRAS) study }\end{array}$ & $\begin{array}{l}\text { Fasting albumin- } \\
\text { corrected } \\
\text { calcemia* }\end{array}$ & $\begin{array}{l}\text { Cresolphthalein } \\
\text { complex one method } \\
\text { (CV 3\%) }\end{array}$ & $\begin{array}{l}\text { American Diabetes } \\
\text { Association } \\
\text { criteria }{ }^{\dagger} \text {, drug Rx }\end{array}$ & $\begin{array}{l}\text { Blood test of subjects } \\
\text { attending the 5-year } \\
\text { follow-up visit of the } \\
\text { IRAS study }\end{array}$ & $\begin{array}{l}\text { Age, sex, ethnicity, } \\
\text { clinic location, BMI, } \\
\text { family history of } \\
\text { diabetes, fasting and } 2 \mathrm{~h} \\
\text { glucose concentrations, } \\
\text { insulin sensitivity } \\
\text { index, acute insulin } \\
\text { response, eGFR, } \\
\text { diuretic drugs }\end{array}$ \\
\hline
\end{tabular}

* Albumin-corrected calcium $(\mathrm{mmol} / \mathrm{L})=$ calcium $(\mathrm{mmol} / \mathrm{L})+0.2 \times(40-$ albumin $[\mathrm{g} / \mathrm{L}])$

† Fasting Plasma Glucose $\geq 126.0 \mathrm{mg} / \mathrm{dL}(7 \mathrm{mmol} / \mathrm{L})$ or $2 \mathrm{~h}$ plasma glucose $\geq 200 \mathrm{mg} / \mathrm{dL}(11.1 \mathrm{mmol} / \mathrm{L})$ after a 75 -g oral glucose load

₹ A nonlinear association between total serum calcium and risk of diabetes has also been reported 
Supplemental Figure S1: Association between serum calcemia and risk of type 2 diabetes mellitus in three prospective available studies
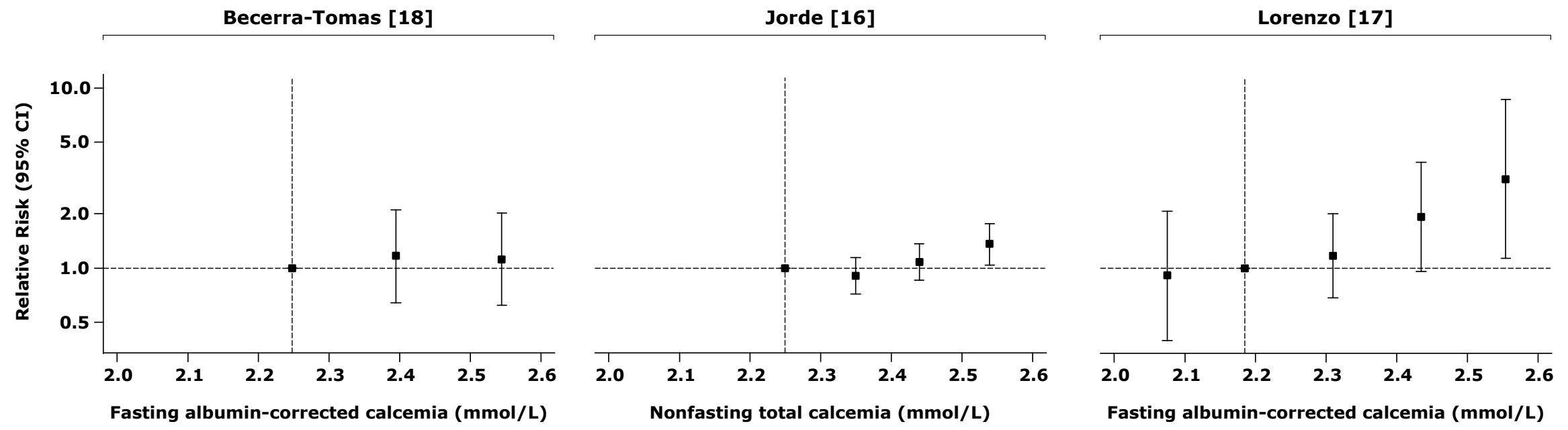

Dotted vertical lines indicate reference values

Supplemental Figure S2: Albumin-calcium binding capacity and albumin-adjusted calcium estimation

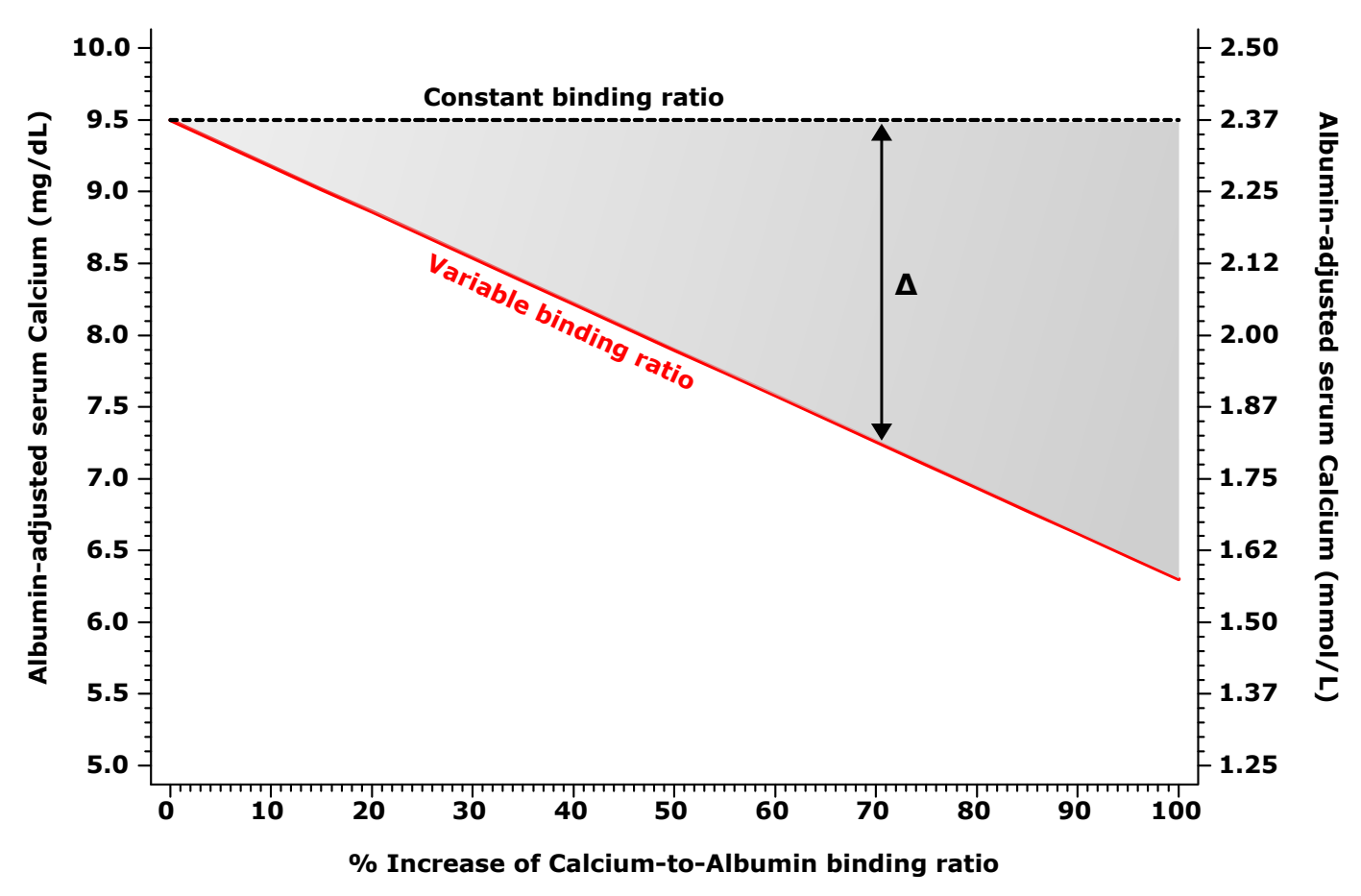

The formula to calculate albumin-adjusted serum calcium [Total calcium $\{\mathrm{mg} / \mathrm{dL}\}+0.8(4.0$ - serum albumin $\{\mathrm{g} / \mathrm{dL}\})]$ is based on several assumption. In particular, it assumes that $1 \mathrm{~g} / \mathrm{dL}$ albumin binds approximately $0.8 \mathrm{mg} / \mathrm{dL}$. However, in many circumstances, this ratio is modified by concomitant factors. For example, increased concentration of circulating fatty acids results in an increased albumin-to-calcium binding capacity and in a poor correlation of total calcium with direct measurements of iCa.

In this graph, assuming a total calcium level of $9.5 \mathrm{mg} / \mathrm{dL}$ $(2.37 \mathrm{mmol} / \mathrm{L})$ and a normal level of albumin $(4 \mathrm{~g} / \mathrm{dL})$, the two lines show the estimated albumin-adjusted serum calcium accounting (solid red line) and not accounting (dotted black line) for a potential increase of calcium-to-albumin binding ( $x$ axis). $\Delta$ indicates the difference between the two estimates. 
Table 1: Baseline characteristics of the study population ( $\mathrm{N}=2350)$ according to incident (Yes) and non-incident (No) cases of type 2 diabetes.

\section{Variable}

\section{Age (years)}

Body mass index $\left(\mathrm{kg} / \mathrm{m}^{2}\right)$

Systolic blood pressure $(\mathrm{mmHg})$

LDL-cholesterol $(\mathrm{mmol} / \mathrm{L})$

HDL-cholesterol (mmol/L)

Triglycerides $(\mathrm{mmol} / \mathrm{L})^{\mathrm{b}}$

Fasting plasma glucose $(\mathrm{mmol} / \mathrm{L})$

C-reactive protein $(\mathrm{mg} / \mathrm{L})$ b

HOMA-IR b

Smoking (yes) c

Family history of diabetes (yes) ${ }^{\mathrm{c}}$

Education (years) $b$

Alcohol (g/week) ${ }^{b}$

Physical activity (kcal/day) b

Serum active calcium $(\mathrm{mmol} / \mathrm{L})$

\begin{tabular}{|c|c|c|c|c|c|c|}
\hline \multicolumn{7}{|c|}{ Mean/Standard Deviation or Median/Interquartile Range } \\
\hline \multicolumn{2}{|c|}{ Total $(\mathrm{N}=\mathbf{2 3 5 0})$} & \multicolumn{2}{|c|}{ Yes $(N=140)$} & \multicolumn{2}{|c|}{ No $(N=2210)$} & ${ }^{a}$ p-value \\
\hline 52.9 & 5.2 & 53.3 & 5.0 & 52.9 & 5.2 & 0.361 \\
\hline 26.7 & 3.4 & 29.0 & 3.9 & 26.6 & 3.3 & $<0.001$ \\
\hline 134 & 17 & 134 & 15 & 133 & 17 & 0.499 \\
\hline 4.04 & 1.01 & 4.09 & 1.00 & 4.04 & 1.01 & 0.555 \\
\hline 1.30 & 0.30 & 1.21 & 0.28 & 1.30 & 0.30 & $<0.001$ \\
\hline 1.11 & $0.81-1.55$ & 1.45 & $1.04-2.20$ & 1.09 & $0.80-1.52$ & $<0.001$ \\
\hline 4.58 & 0.47 & 4.92 & 0.54 & 4.56 & 0.46 & $<0.001$ \\
\hline 1.26 & $0.70-2.39$ & 1.68 & $0.94-2.41$ & 1.23 & $0.69-2.39$ & 0.020 \\
\hline 2.20 & $1.65-3.06$ & 3.17 & $2.12-4.80$ & 2.16 & $1.62-2.96$ & $<0.001$ \\
\hline $33 \%$ & - & $34 \%$ & - & $33 \%$ & - & 0.817 \\
\hline $27 \%$ & - & $30 \%$ & - & $27 \%$ & - & 0.366 \\
\hline 8 & $6-10$ & 8 & $6-10$ & 8 & $6-10$ & 0.117 \\
\hline 32 & 6-91 & 39 & 4-108 & 31 & $6-90$ & 0.907 \\
\hline 285 & $151-481$ & 275 & $122-509$ & 287 & $153-479$ & 0.735 \\
\hline 1.18 & 0.05 & 1.17 & 0.06 & 1.18 & 0.05 & 0.587 \\
\hline
\end{tabular}

HOMA-IR: Homeostatic model assessment of insulin resistance

a Difference Yes vs No

b Data reported as median and interquartile range

c Data reported as \% 
Figure 1: Hazard ratios and 95\% confidence interval (bars) of type 2 diabetes mellitus by quartiles of baseline active calcium levels.
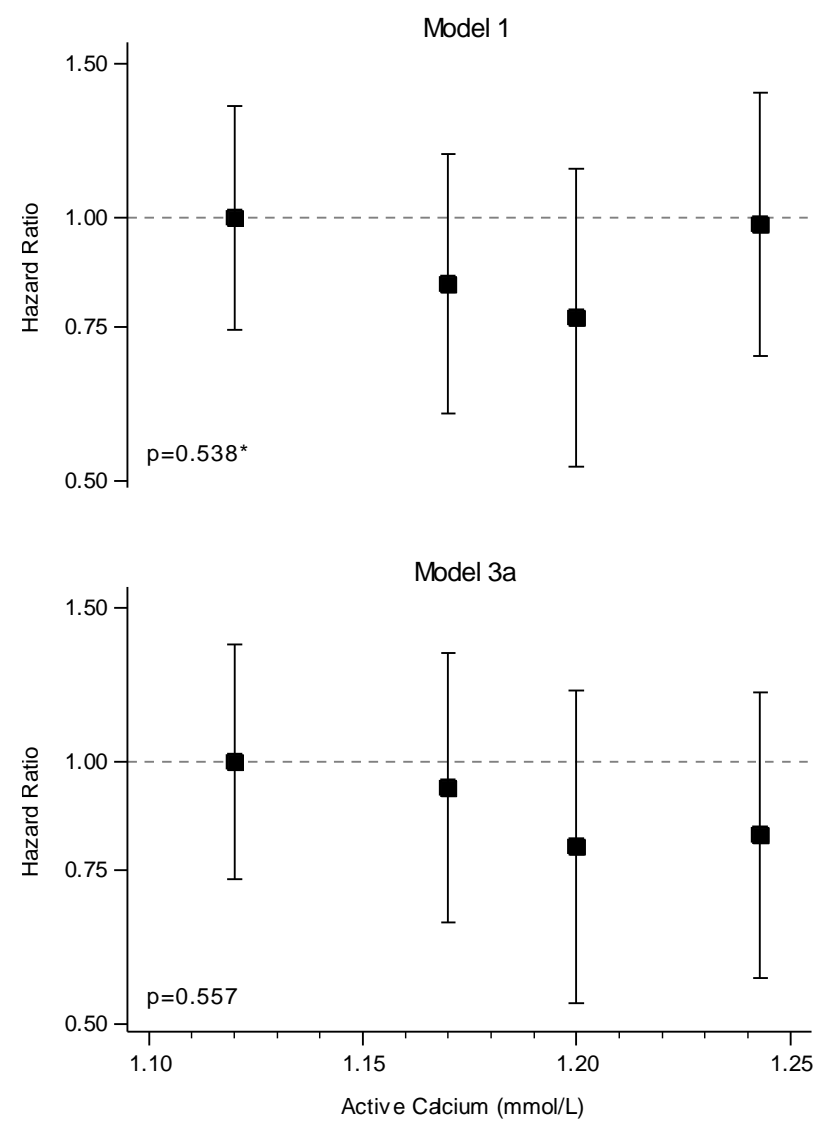

Model 2

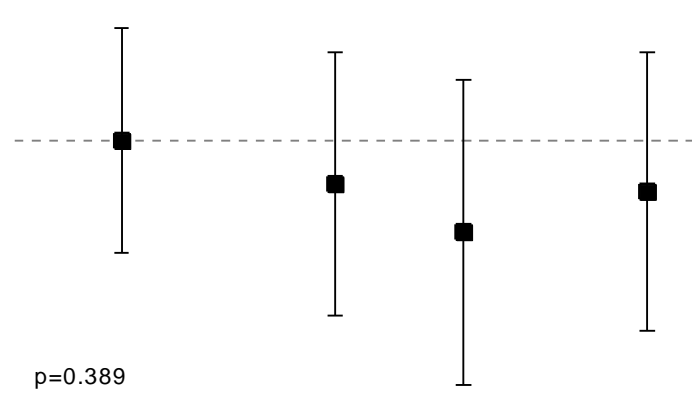

Model 3b

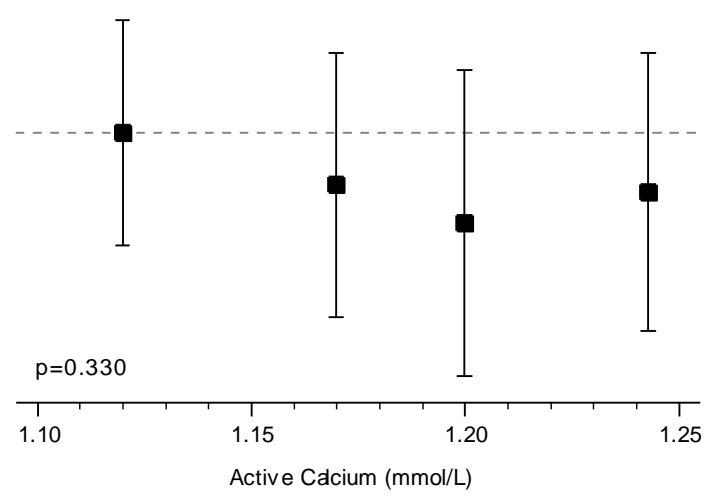

* $\mathrm{p}$-v alue for trend 